\title{
DETERMINING FAIR RENTAL VALUE OF LAND IN THE HUNGARIAN VALUATION PRACTICE - A METHODOLOGICAL APPROACH
}

\author{
Ferenc Buzás ${ }^{1}$, László Posta1, Sándor Kiss² \& István Mezô² \\ University of Debrecen ${ }^{1}$, Biblio-Markt Ltd. ${ }^{2}$
}

\begin{abstract}
The directive of 1666/2015. (IX. 21.) called 'Land for Farmers!' has changed not only the legal terms and conditions but also the economic basis of land use in the relation of land use and resulting derivative demand. Institutionalized rental fees can be modified to market level only if it is confirmed by qualified expert's report hired by the new land owner. Setting a fair rental value has quite a few methodological approaches. Due to the lack of a legally recommended calculation process, authors hereby are presenting a method to calculate fair rental value that is beneficial for both renter and owner. Foreign rental conditions related to the topic are also concerned in the article.
\end{abstract}

Keywords: land rent, rental value, land valuation method, land use

(JEL Classification: Q15)

\section{INTRODUCTION}

The recently privatisation of state owned agricultural lands raised several questions and problems in Hungarian agriculture, but one of the most controversial was the measure of the rental value. The rental value of the state owned lands was fixed institutionally by legal way - significantly below the market level $\left(1250 \mathrm{HUF} / \mathrm{GCV}^{{ }^{*}}\right)$ - but after the privatisation it can be modified by the new owners. Fair rent helps producers and landlords estimate returns from cash, share and flexible rental arrangements. The most important question for the renter and land lord is that how much can be the fair rental value, which can be acceptable on long term for both

Modification of land rent by the two partners can be made by the opinion of an expert. In most cases land market based evaluation is accepted, but in many cases there are problems with comparison data of local Land Administration Office. In cases of some localities there are no concrete values concluded, but because of combined rent it is tied to an amount of yield, while within a family or among relatives land rents are altered from market values. In many cases recorded data are not punctual enough.

Nowadays, due to subsidies and raised level of average agricultural incomes there is a demand dominancy in land market. On the other hand in the field of land use supply and demand is differential (Naárné et al., 2013) In some territories, mainly in localities with good land quality, owners make competition among the potential users or tenants, while

1 Gcv - Gold crown value - measure unit, which indicates the quality of the agricultural land in other territories tenants try to reduce the land rent because of the risk of the market and the weather.

So, consideration of land rent is not a responsibility of the expert. Concluding a fair rental value, local specialties and values have to be considered, but the long term interests of the owners and users also have to be counted. The method of land market based value alone is not eligible for these requirements, yield based evaluation is also recommended, which provides the long term interest of both sides. For determining the fair rental value, authors devised a potential method, which is eligible for the high expectations.

\section{LITERATURE REVIEW}

\section{Land rental value in the European Union}

A lease (rent) is an agreement that gives someone ability to use or possess real or personal property for a designated period of time in return for some type of payment. Theoretically, if markets are perfect and transaction costs insignificant, then agricultural land prices and rents are expected to change in parallel.

At the present there are no exact data about the land prices and rents from EU member countries. Through the Eurostat and the relevant national authorities, the European Commission tries to launch of a common methodology agreed between the Member States (EC, 2016).

In the EU the farmland sales market regulations are different from the rental market regulations. (Naárné Tóth, 2005). Three types of rental market regulations exist: rental price regulations, the tenancy duration regulations 
and quantitative land rent regulations. In one third of the EU the maximum rental prices are set by the government. The duration of rental contracts is regulated in some EU countries and influences the rental market's responsiveness to agricultural policy changes. The main institutional regulations are presented in the Table 1. The importance of land renting is typically higher in countries with strong rental market regulations, such as France and Belgium, they have the highest share of rented area (77\% and $75 \%)$ among all the EU countries.

Table 1. Rental market regulations in some EU countries

\begin{tabular}{|c|c|c|c|}
\hline & $\begin{array}{l}\text { Min/ } \\
\text { Max } \\
\text { rental } \\
\text { price }\end{array}$ & $\begin{array}{l}\text { Min/Max, average } \\
\text { tenancy duration }\end{array}$ & $\begin{array}{l}\text { Other rental market } \\
\text { regulations \& norms }\end{array}$ \\
\hline Belgium & Max rent & $\begin{array}{c}\text { Min 9/Max 27(99) } \\
\text { Usually } 9\end{array}$ & - \\
\hline Finland & No & Max 10 Average 5-6 & - \\
\hline France & $\begin{array}{l}\text { Min \& } \\
\text { Max } \\
\text { rent }\end{array}$ & $\begin{array}{c}\text { Min 1/Max } 25 \\
\text { Usually } \\
9 \text { or } 18\end{array}$ & $\begin{array}{c}\text { Inheritable } \\
\text { rental contracts, } \\
\text { automatically renewed }\end{array}$ \\
\hline Germany & No & No Average 6-11.5 & $\begin{array}{l}\text { Subject to state } \\
\text { approval }\end{array}$ \\
\hline Greece & Min rent & No $<4$ years & - \\
\hline Ireland & No & No & $\begin{array}{c}\text { Conacre rental } \\
\text { agreements }\end{array}$ \\
\hline Italy & No & $\begin{array}{l}\text { No; average arable } \\
\text { crops 2-5, fruit crops } \\
5-10\end{array}$ & $\begin{array}{c}\text { Possibility of } \\
\text { contracting with the } \\
\text { assistance of farmer } \\
\text { associations }\end{array}$ \\
\hline Netherlands & Max rent & Min 6 (until 2007) & - \\
\hline Spain & No & Min 5 & - \\
\hline Sweden & No & No & - \\
\hline $\begin{array}{c}\text { United } \\
\text { Kingdom }\end{array}$ & No & $\begin{array}{l}\text { In Scotland for new } \\
2003 \text { Act tenancies } \\
\text { max } 5, \text { min } 15\end{array}$ & $\begin{array}{l}\text { Northern I. - conacre } \\
\text { rental agree-ments; } \\
\text { Scotland - Traditional } \\
\text { short duration } \\
\text { tenancies; England - } \\
\text { traditional tenancies } \\
\text { \& farm business } \\
\text { tenancies }\end{array}$ \\
\hline
\end{tabular}

Source: Swinnen et al., 2010

The value of the rent is influenced by several way (Swinen et al., 2010). Agricultural policy especially the subsidies has dominant influence on rents. The impact of SPS on land rents appears to be stronger than on land sale prices. Developments in rental prices were heterogeneous: since 1992 real rental prices declined by around $25 \%$ in Finland and increased by around 55\% in Spain (Strelecek et al, 2010). Trying to estimate the impact of subsidies on farmland value, the empirical studies effected by Swinnen et. al (2008) shows that the land price elasticity of $1 \%$ increase in subsidies/returns, varied between - 0,12-0,69. Similar result found O'Neill and Hanrahan (2013), they study point out that the high degree of inertia in rents means that the impact of previously capitalised agricultural policy persists through time. Rental prices for agricultural land tend to be more regulated by the government than purchase prices.
Van Herck et al (2013) analysed the impact of increasing direct payments on land rents in six new EU member states. They find that up to 25 eurocents per additional euro of direct payments is capitalised in land rents.

G. Breusted and H. Habermann (2009) reveal that the marginal incidence of regional per-hectare premiums in the EU is significantly higher than one. This is on first sight controversial since the subsidy more than fully capitalizes into the land rental price, in addition other important determinant of rental prices can be the regional livestock density, as well.

It must be mentioned that the dynamics of land prices and rents generated by the supports of EU states can be followed in the states waiting for EU accession (Bojnec, 2011). These procedures, however, are realized much faster in these developing areas than in Western-European countries, where land prices and rents were disposed in centuries (Clark, 2001). In the overseas there are partial differences compared to European price dynamics. In those areas reaction to declining crop prices and farm incomes was relatively flexible concerning land prices and rents (Dobbins - Cook, 2016). Similar effect though not a unique exception - could be observed in several member states of the EU as well. (Good - Boyle, 2017).

\section{Land prices and land rents in Hungary}

Land prices differs largely by regions and by counties, in 2014 the difference between the maximum and minimum values was 53\%. We can't find serious differences between the Western and Eastern part of the country, the prices are determined more by the land quality, and local factors (location, accessibility, economic and demographic situation etc.) (Buzás - Kiss, 2012).

Figure 1: Land prices and growth rate (previews year $=100 \%$ ) in Hungary

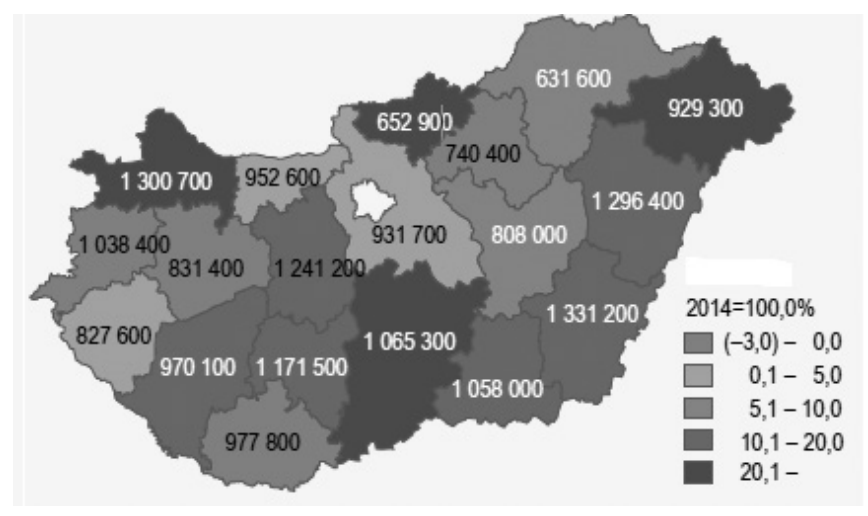

Source: Hungarian Central Statistical Office (2014) - by the data of

\section{National Tax and Customs Administration}

According to data of Central Statistical Office (2014), $73 \%$ of total agricultural land sold in 2014 was arable land, 12\% forest and $11 \%$ meadow or grass land. The remaining $4 \%$ was vineyard and orchard. There were essential differences between regions of the country. Sale of arable land was dominant throughout the country. With 34\% Bács-Kiskun county showed the lowest 
rate, while Győr-Moson-Sopron county had the highest figure with $86 \%$. From 2014 the increase in land prices have changed from region to region and rate of growth has been decreasing.

Figure 2: The rental value of arable land and the change of the rent in Hungary by counties

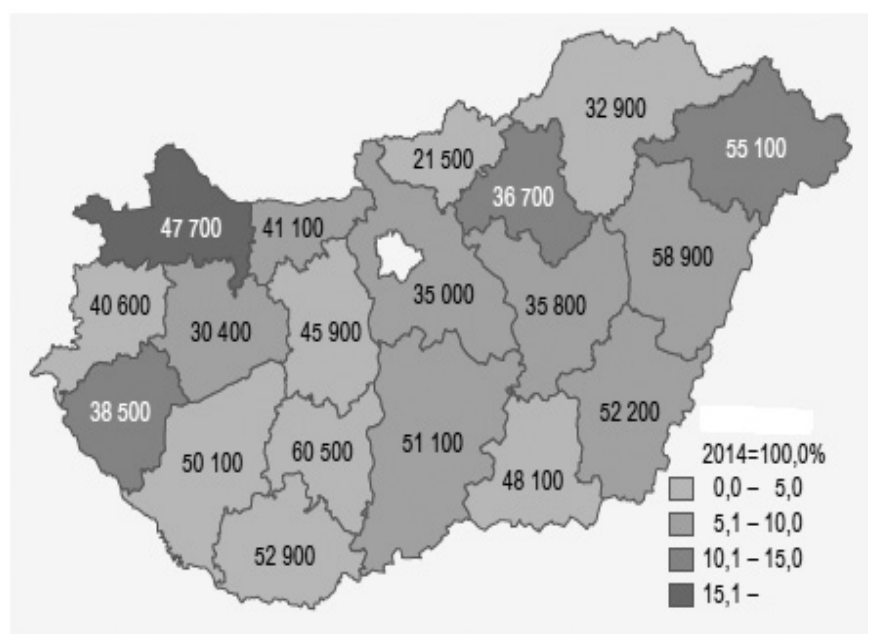

Source: Hungarian Central Statistical Office (2014)

According to the data of Central Statistical Office, 57\% of arable land are used as rent. In Trans-Danubian areas the ratio is higher $(66 \%)$, while in the Great Plain and Northern regions the ratio is $51 \%$. There are significant differences between types of land use in different regions. In Hajdú-Bihar county rent is also spread, but mainly owners cultivate land.

As for rental fees, significant heterogeneity can be traced in different regions and counties as well. While the Northern part of the Great Plain represents rates of the national average, due to its favourable disposition, Hajdú-Bihar county belongs to the highest rated regions concerning rental fees. Concerning the average rental value of Western and Eastern counties we can't find great differences (43 $589 \mathrm{HUF} /$ ha and $44270 \mathrm{HUF} /$ ha), which can be explained probably by the average land quality (19,69 Gcv/ha respectively $20,23 \mathrm{Gcv} / \mathrm{ha})$.

Figure 3: The changes in land price and land rental value of arable land in the last years.

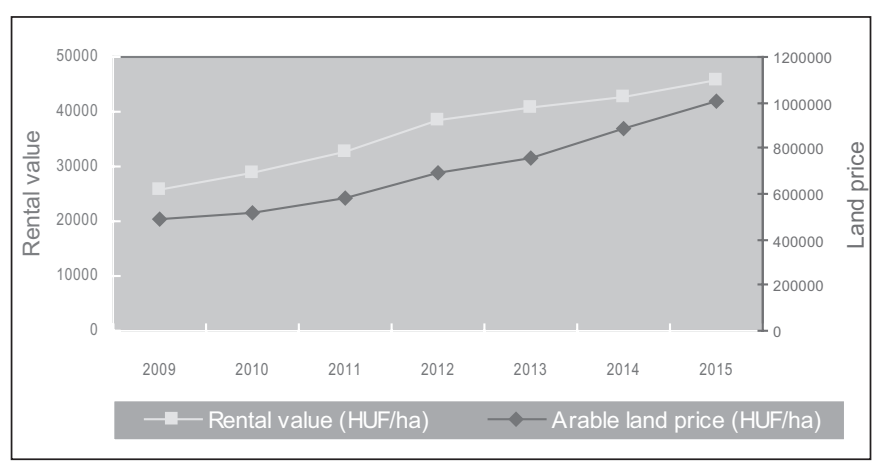

Source: Hungarian Central Statistical Office (2014)
Joining the EU in 2004 and thus getting agricultural subsidies has influenced national land market conditions in a big way. By 2013, the rate of EU support in Hungary reached the average EU level, and thus, through derivative demand, it was a price sensitive factor concerning both sale price and rental fee of land. Based on empirical experience, growth in EU support leads to increasing land prices and rental fees.

Figure 4: The ratio and connections between land price and value of the rent - by counties

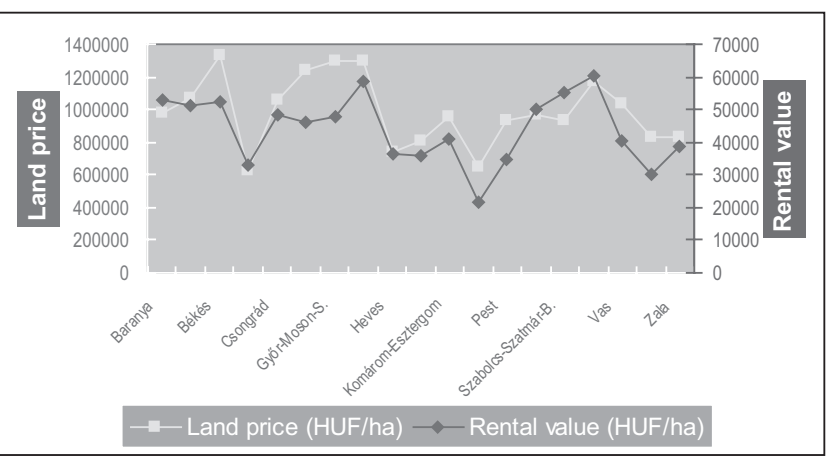

Source: Hungarian Central Statistical Office (2014)

In the majority of the counties, rental fees were 4-6\% of market price of land. However, in Trans-Danubian areas rental fees were usually below $4 \%$ of market price, i.e. relatively high land prices combined with lower rental fees, while in eastern regions, rental fees were $6,8 \%$ of market price.

Figure 5: Rental value and the quality of the arable land by counties

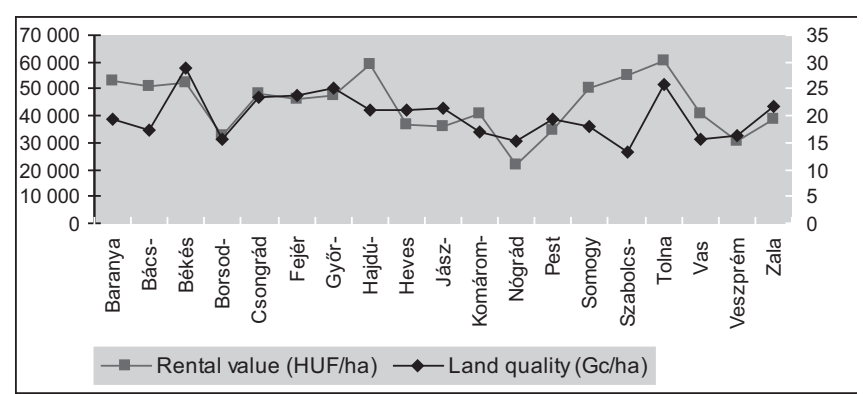

Source: own graph, by the data of Hungarian Central Statistical Office (2014)

\section{Empirical Analysis}

We tried to determine the connection between the land price, rental value and land quality - for that reason we made a correlation analyses. The results of correlation test can be seen in the Table 2 . 
Table 2: The results of correlation test

\begin{tabular}{|l|c|c|}
\hline & Rental value & Land quality \\
\hline Land price & 0,760 & 0,652 \\
\hline Rental value & & 0,420 \\
\hline Land quality & 0,420 & \\
\hline
\end{tabular}

Source: own calculation, by the data of Hungarian Central Statistical office (2014)

As it can be seen in Table 2. we found significant correlation between land price and rental value, and land price and land quality, but correlation is low between rental value and land quality.

\section{The methodological basis of determining land rental fee}

Unanimously accepted legal regulation or methodology for determining rental fee of land in Hungary is not available. In such cases, guidelines of land valuation are to be applied. Decree of 54/1997. (VIII. 1.) Annex No.1. contains the methodology of market comparison assessment, while Annex No.2. contains the methodology of income yield-based assessment approach.

Methodology of assessment is based on both national regulations and European Valuation Standards (EVS 2003) set by The Group of European Valuers (TEGOVA), including S4.01.-S4.76. parts and GN7.37 (for capitalisation method) and S.4.01.-S.4.76, GN7.49 (for market approach). The details of calculations and the detailed methodology are used by the proper decision of the valuer, which many times can be controversial.

\section{A. The market data comparison approach}

Principles of assessment are based on territorial, land quality and land use concept. Within the principle of territorial concept, zoning, location, and accessibility are to be concerned based on representative data available from the Land Administration Office of the district governmental offices. Basic data must be analyzed and filtered by descriptive statistics (average, median, modus, minimum and maximum figures).

Due to the fact that concerning Gold crown value (which is used for measuring the quality of land) there might be significant differences between average data and actual land quality, it is of crucial importance that the assessment is made by an expert. Thus, based on the concept of land quality, comparative data and land size are also taken into consideration (Szúcs, 1998). Unit-based land rental fee must be corrected in accordance with land use concept, i.e. territorial size, rate of irrigation, landmarks and cultivation limiting/ aiding elements (Naárné, 2009) Correction must always be explained and should not be over $+/-30 \%$.

To determine the final rental market value: the corrected average rental value (HUF/ha) can multiplied with the size of the land (ha).

\section{B. Income based approach}

\section{Land rent concept}

David Ricardo said: "Rent is that portion of the produce of earth which is paid to landlord for the use of original and indestructible powers of the soil."

According to the theoretical principles of economics, land rent is the temporary transfer of land use right in exchange of rental fee. It occurs when the advantages outweigh all disadvantages for both parties. The lease is a contract subject to legal effect and includes a fixed fee paid to the owner.

There are different ways to calculate land income (rent) in economic theory. However, in practice there are two applied methods:

\section{a. Income method based on capitalization \\ $\underline{b}$. The residual value method}

The basis of rental fee is land income (as annuity). Land income means interest on land capital and/or the yield of the capital invested in the land - or part of it. It is actually part of the profit that remains after the deduction of opportunity cost of capital invested (excluding land capital). In conclusion, it is the land owner who is entitled to land income. In case of cultivation of self-owned land, no differentiation is necessary.

\section{a.) The rent (income) capitalisation - inverse method}

In accordance with the above mentioned, in the case of capitalization concept, the basis of calculation should be the realized sales price of land in the region, and market comparison approach should be applied (i.e. unit-based (specific) value calculation based on territorial, land quality and land use concept).

- income based method is based on capitalization of rent , i.e. theoretical rental fee can be calculated from land value with the help of the formula

- land income (rental fee) $=$ land value $\mathrm{x}$ interest rate of capitalization + land tax*

*Note: It is determined by local governments.

The land value (price) - can be determined by market comparison approach

For capitalisation rate - can used the average capitalisation rate of the mortgage banks. The current value of capitalisation rate of major mortgage banks in Hungary are presented in the Table 3.

When defining capitalization rate, it is accepted to apply public interest rates announced by mortgage banks applied in land evaluation. However, in some cases it is more precise to calculate the ratio of average sale price and average rental fee typical in the given region or location. A fair approach is to calculate the ratio of the two and thus represent local and national tendencies, as well. 
Table 3: Capitalisation rate recommended by the mortgage banks for determining land (and rental)values

\begin{tabular}{|l|c|c|c|c|}
\hline \multirow{2}{*}{} & \multicolumn{2}{|c|}{ Budapest } & \multicolumn{2}{c|}{ Rural area } \\
\cline { 2 - 5 } & Min. & Max. & Min. & Max. \\
\hline Arable land, meadow & $4,5 \%$ & $5,5 \%$ & $5 \%$ & $6 \%$ \\
\hline Orchard, vineyard & $8 \%$ & $9 \%$ & $8 \%$ & $9,5 \%$ \\
\hline
\end{tabular}

Source: own calculation (averages) in 2017, based on banks information sources

In the EU, the capitalization rate moved in 2007 on the scale of $0.83 \%$ (Belgium) to $4.26 \%$ (Sweden). In six states (Czech Republic, Denmark, Germany, Netherlands, Finland and Slovakia), the capitalization rate oscillated within 2-3\% (Strelek et. al).

\section{b.) The method of residual value}

The other applied method is based on residual value, i.e. alternative cost of capital is deducted from entrepreneurial income:

land rental fee $=$ value of production - (production cost + interest on fixed and current assets invested in production)

The final rental fee can be set by the ratio of the two: market based value and income capitalisation value. It is highly necessary when free market value attitude is limited, rights to exercise, shared ownership (land versus infrastructure), etc.

\section{RESULTS, CONCLUSIONS}

In practice, the renter is motivated to find land below market value, while the owner is motivated to lease or sell their land above this value. Final value is defined by bargaining power.

In case of market comparison approach, it is possible to calculate rental fee related to the given time and location (microenvironment). However, income based approach is a method that allows us to see macro-environmental effects in the long run. By the application of a combined method, the future interest of both the renter and the owner is correctly represented.

In the current practice in Hungary the increase of land prices generated by the supports has raised the rents as well, which is an advantage for land owners, while a definite disadvantage for tenant farmers. However, the new budget directives for agricultural policy in the EU are to partly decrease the supports, which will have an effect on profits, and indirectly will affect rental market, too. It is the landowners' interest to calculate a balanced return of capital and rent in the long run. To do so, it is of crucial importance that alternative costs show a return and at the same time, economic profit is also realized. For the realisation of these two conditions, when calculating rents, not only the self-generating market pricing needs to be considered, but also the profit producing ability of the tenants. The method recommended by the authors fulfils both conditions.

\section{REFERENCES}

Bojnec S. (2011): Land Markets in the EU Candidate Countries of Croatia, Former Yugoslavia Republic of Macedonia and Turkey. Factor Markets Working Paper no.1. September 2011.

Buzás F.- Kiss S. (2012): A termőföldértékelés tapasztalatai Javaslatok a vonatkozó jogszabályi háttér átdolgozásához. A termőföldpiac és az értékelés kérdései - EUFIM szakmai konferencia 2012. márc. 23. Magyar Ingatlanszövetség. Budapest.

Clark G. (2001): Land Rental Values and the Agrarian Economy: England and Wales, 1500-1912. European Review of Economic History 6(03).

Dobbins C. - Cook K. (2016): Indiana Farmland Values and Cash Rents Continue Downward Adjustments. Purdue Agricultural Economics Report.

EUROPEAN COMMISSION - EUROSTAT Directorate E: Sectoral and regional statistics (2016): Agricultural Land Prices and Rents data for the European Union.

European Comission (2016): Agricultural Land Prices and Rents data for the European Union. Research Paper. Directorate E: Sectoral and regional statistics. Reference: AAP WG/2017/1/16 Version 1.0

F. Strelecek - J. Lososova- R. Zdenek (2010): The relations between the rent and price of agricultural land in the EU countries Agric. Econ. - Czech, 56, 2010 (12): 558-568.

G. Breustedt - H. Habermann (2009): Determinants of Agricultural Cash Rents in Germany: A Spatial Econometric Analysis for Farm-Level Data - University of Kiel, Germany. Contributed Paper prepared for presentation at the International Association ofAgricultural Economists Conference, Beijing.

J. Swinnen - P. Ciaian - A. Kancs (2008): Study on the Functioning of Land Markets in the EU Member States under the Influence of Measures Applied under the Common Agricultural Policy - Final Report. Centre for European Policy Studies (CEPS). Bruxelles.

J. Swinnen - P. Ciaian - A. Kancs - Vranken L. (2010): EU Land Markets and the CAP e-version. Centre for European Policy Studies. Bruxelles.

J. Swinnen - P. Ciaian - A. Kancs (2008): Study on the Functioning of Land Markets in the EU Member States under the Influence of Measures Applied under the Common Agricultural Policy - Final Report. Centre for European Policy Studies (CEPS) Brussels.

K. Van Herck J. Swinnen - L. Vranken (2013) : Direct Payments and Land Rents Evidence from New Member States. Comparative Analysis of Factor Markets for Agriculture across the Member States. Working Paper. No. 62. Bruxelles.

KSH (Hungarian Central Statistical Office - 2014): Mezőgazdasági termőföldárak és bérleti díjak, 2015. Budapest.

Naárné Tóth Zs. (2009): A termőföld közgazdasági értéke és piaci ára. Agroinform Kiadó. Budapest.

Naárné Tóth Zs.- Tóth T. (2005): Földtulajdon és földhasználat főbb összefüggései hazánkban. Agronapló. 2005. $10 \mathrm{sz}$.

Naárné Tóth Zs.- Baranyai Zs.- Vinogradov Sz. (2013): A szántóföld árának és közgazdasági értékének összefüggései Magyarországon. LV. Georgikon Napok.

P. Good - G. Boyle (2017): Land Market Review and Outlook 2017. Society of Chartered

Surveyors Ireland - Teagasc Agricultural Economics and Farm Surveys Department. Dublin. 
S. O'Neill and K. Hanrahan (2013): An Analysis of the Capitalisation of CAP Payments into Land Rental Rates in Ireland. Comparative Analysis of Factor Markets for Agriculture across the Member States. Working Paper. No. 68. Bruxelles.

Szúcs I. (1998): A föld ára és bére. Agroinform Kiadó. Budapest. 